\title{
Mapping Potential Planting Areas for Golden Camellias in North Vietnam
}

\author{
Tran Duc MANH ${ }^{1}$, Tran Van DO ${ }^{1, *}$, Nguyen Van TUAN ${ }^{1}$, Phung Dinh TRUNG ${ }^{1}$, \\ Nguyen Toan THANG ${ }^{1}$, Dang Van THUYET ${ }^{1}$, Dao Trung DUC ${ }^{1}$, \\ Mai Thi LINH ${ }^{1}$, Ninh Viet KHUONG ${ }^{1}$, Vu Tien LAM ${ }^{1}$, \\ Nguyen Huu THINH ${ }^{1}$, Hoang Thanh SON ${ }^{1}$, Trinh Ngoc BON ${ }^{1}$, \\ Ho Trung LUONG ${ }^{1}$, Vu Van THUAN ${ }^{2}$ and Nguyen Thi Thu PHUONG ${ }^{1}$
}

\author{
${ }^{I}$ Silviculture Research Institute, Vietnamese Academy of Forest Sciences, Hanoi, Vietnam \\ ${ }^{2}$ Centre for Applied Silviculture Research and Extension, Silviculture Research Institute, Vietnamese \\ Academy of Forest Sciences, Hanoi, Vietnam.
}

('Corresponding author's e-mail: dotranvan@hotmail.com)

Received: 6 January 2019, Revised: 29 January 2020, Accepted: 19 February 2020

\begin{abstract}
This study mapped potential areas for planting golden camellias in Cao Bang province, North Vietnam. Natural conditions (elevation above sea level, annual precipitation, and annual air temperature), where 6 golden camellia species (Camellia impressinervis, C. kirinoi, C. megasepala, C. tuyenquangensis, C. hamyenensis, and $C$. tienii) naturally distribute, were used for mapping. Three map layers (topography, precipitation, and air temperature) were used. Each main condition was classified into 3 levels for planting, "not suitable", "suitable", and "very suitable". The results indicated that 1,970 ha, accounting for $0.3 \%$ of the total land area of Cao Bang province, was classified as "very suitable" for planting golden camellias. "Suitable" areas counted for $62.7 \%$, and "not suitable" areas accounted for $37 \%$ of the total land area, respectively. Mapping suitable planting areas is the 1st step for the successful planting of any species. It is recommended that golden camellias should be first planted in very suitable areas, after which planting may be extended to some suitable areas.
\end{abstract}

Keywords: Active ingredient, Camellia L., Ethnic communities, Natural condition, Poverty reduction

\section{Introduction}

Golden camellias belonging to genus Camellia L, family Theaceae, are shrubs and small-sized trees [1]. These species have flowers with yellow colors (Figure 1). At maturity, under natural conditions, they are 3-12 m tall. In southern China and Vietnam, approximately 60 golden camellias species have been described [2,3]. Of those, around 40 species were found in Vietnam [4-7]. 

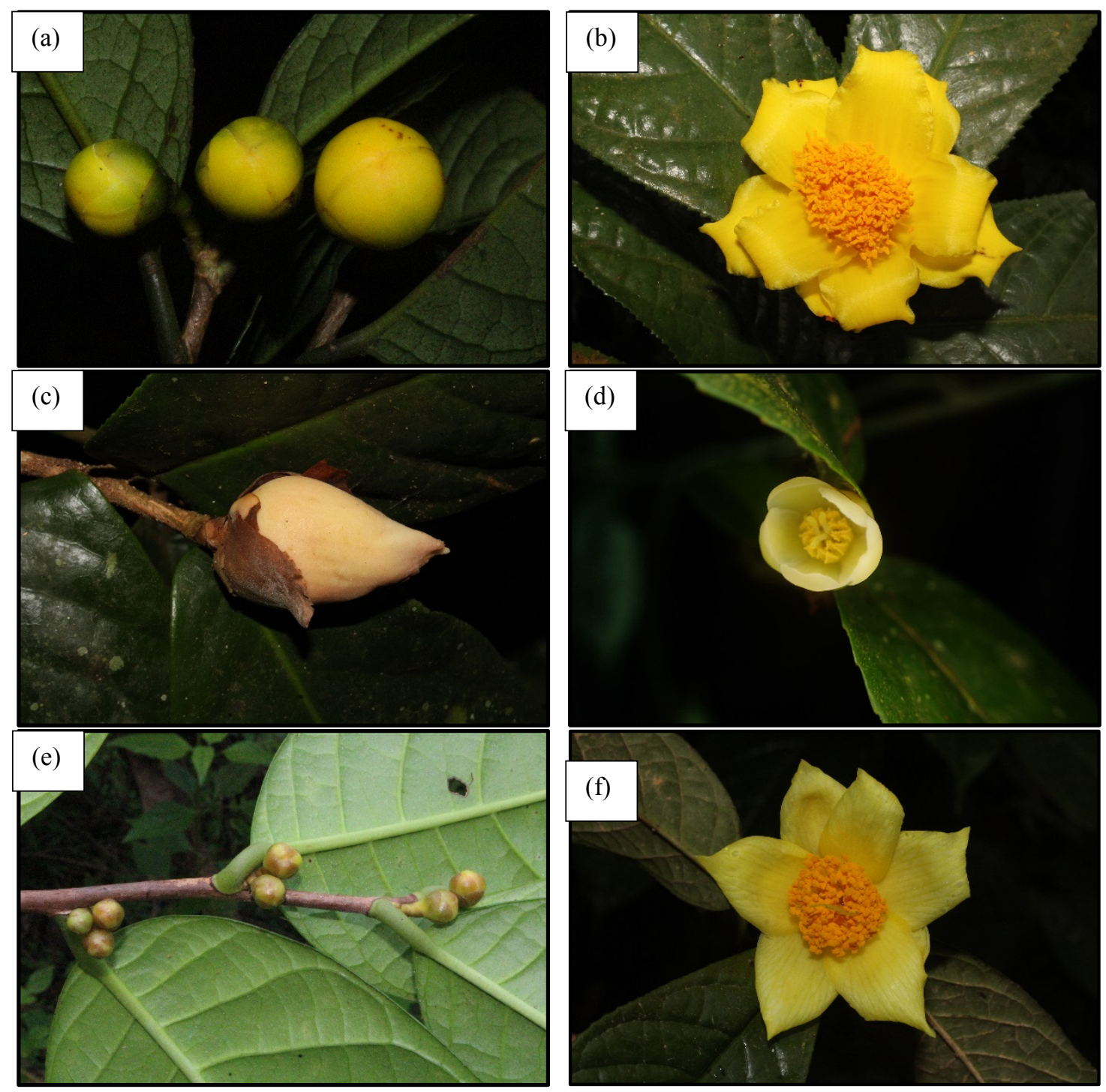

Figure 1 Flowers and buds of golden camellias in Vietnam. Camellia tuyenquangensis (a), C. tienii (b), C. megasepala (c), C. kirinoi (d), C. hamyenensis (e), and C. impressinervis (f).

Camellia species contain active ingredients such as flavonoids, polyphenols, polysaccharides, and tea saponins [8-11]. Extractions from Camellia species are able to inhibit cancer, control blood pressure, blood lipid, and cholesterol, and prevent atherosclerosis [12]. Golden camellias have been traditionally used like green tea (Camellia sinensis). The flowers of golden camellias are more widely used than the leaves, which is different from green tea. Extracts from golden camellias are valuable for superoxide anions, antioxidant activities, and hydroxyl free radical scavenging assays [13]. In traditional medicine, golden camellias have been used for treating sore throat, diarrhea, high blood pressure, and irregular menstruation, and in cancer prevention [11].

Because of the high health benefits, the commercial value of golden camellias is much higher than that of green tea. In Vietnam, it cost 600 - 700 US\$ for $1 \mathrm{~kg}$ of dry flowers, and 40 - 50 US\$ for $1 \mathrm{~kg}$ of 
dry leaves [14]. A 2.5 - $3 \mathrm{~m}$ tall tree of C. euphlebia can yield up to $3 \mathrm{~kg}$ of fresh flowers, equal to $0.5 \mathrm{~kg}$ dry per year. Such flower yield indicates the potential of golden camellias for poverty reduction in mountainous areas in Vietnam. However, to grow any species successfully, selecting suitable planting areas is a prerequisite. This study aims to map potential planting areas for golden camellias in Cao Bang province, North Vietnam.

\section{Materials and methods}

\section{Mapping site}

Mapping was conducted in Cao Bang province, North Vietnam (Figure 2). Cao Bang borders China in the North and other provinces of Vietnam, including Ha Giang, Bac Kan, and Lang Son, in the East, South, and West. There are 5 main ethnic minorities (Tày, Nùng, Giao, H’Mong and Sán Chỉ) living in Cao Bang, which is known as one of the poorest provinces in Vietnam, and more than $95 \%$ of the land is classified as mountainous.

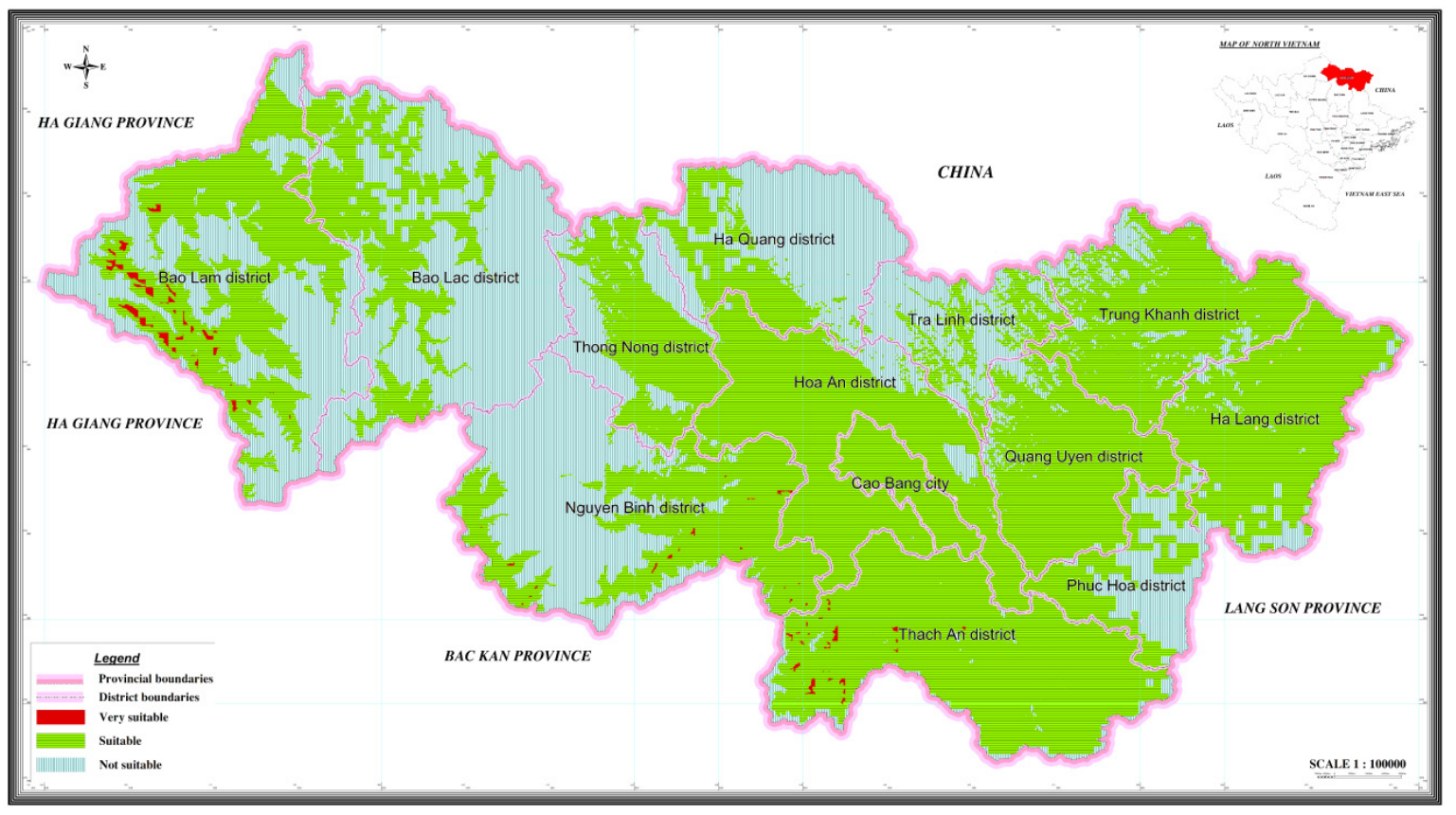

Figure 2 Map of potential areas for planting golden camellias in Cao Bang province, North Vietnam.

\section{Gathering natural conditions of golden camellias}

There are nearly 40 golden camellias naturally distributed in Vietnam. Of these, about 30 species are naturally distributed in the North. Two golden camellias have been found to have natural distribution in Cao Bang, Camellia impressinervis Hung T. Chang \& S. Ye Liang (Vietnamese name: Chè hoa vàng gân lõm) and Camellia kirinoi Ninh (Vietnamese name: Chè hoa vàng Kiri). C. impressinervis has natural distribution in South China and North Vietnam and is classified as a critically endangered species [15]. Meanwhile, C. kirinoi is an endemic species of Vietnam [16], was first found in Lang Son province, bordering with Cao Bang in the Southeast (Figure 2) and was recently found in Phuc Hoa district, Southeastern Cao Bang, near Lang Son province. C. impressinervis has heavily yellow flowers, which are up to $4.5 \mathrm{~cm}$ in diameter and $13 \mathrm{~g}$ in fresh weight [7,14]. C. kirinoi has light yellow flowers, which are up 
http://wjst.wu.ac.th

to $1.5 \mathrm{~cm}$ in diameter and $1.2 \mathrm{~g}$ in fresh weight (Figure 1) [16].

In Tuyen Quang and Bac Kan provinces, sharing borderlines with Cao Bang, there have been 4 other golden camellias found to have natural distribution, C. megasepala Hung T. Chang \& Tran Ninh (Vietnamese name: Chè hoa vàng $\mathrm{Ba}$ Bể/Chè hoa vàng đài lớn), C. tuyenquangensis D.V. Luong, N.N.H. Le \& N. Tran, sp. nov. (Vietnamese name: Chè hoa vàng Tuyên Quang), C. hamyenensis M. Sealy (Vietnamese name: Chè hoa vàng Hàm Yên), and $C$. tienii Ninh (Vietnamese name: Hải đường vàng/Chè hoa vàng Tiến). These 4 species have large-sized flowers and, therefore, are considered to have potential for planting in Cao Bang. The natural conditions where these 6 species (C. impressinervis, C. kirinoi, $C$. megasepala, $C$. tuyenquangensis, $C$. hamyenensis, and $C$. tienii) are naturally distributed, were ascertained as prerequisite information for mapping potential planting areas for Cao Bang. The information included distribution elevation above sea level, annual precipitation, and air temperature.

\section{Mapping techniques}

Mapping has been widely used to identify species distribution ranges [18], plant diversity [19], and potential tree planting sites [20]. Natural data of concerned parameters are represented on digital maps to find areas meeting desirable conditions. The more natural data and map layers used, the more accurate the maps produced.

There are 3 main conditions governing distribution and growth of golden camellias, (1) elevation above sea level (generally, no golden camellias found in $>850 \mathrm{~m}$ ), (2) annual precipitation (long drying season of $\geq 2$ months of $<50 \mathrm{~mm} /$ month is not a favorable condition, since golden camellias prefer wet conditions/high moisture soil), and (3) annual air temperature ( $>33$ or $<7^{\circ} \mathrm{C}$ is not a favorable condition).

Mapping was conducted on 3 digital maps of Cao Bang, which showed (1) elevation, (2) precipitation, and (3) temperature. Each parameter was classified into 3 levels as (a) not suitable, (b) suitable, and (c) very suitable. The mapping process was as follows:

- If 1 parameter $(a, b$, or $c)$ belonged to "not suitable", entire areas were classified as "not suitable" for planting.

- If all 3 parameters ( $a, b$, and c) belonged to "suitable", entire areas were classified as "suitable" for planting.

- If all 3 parameters (a, b, and c) belonged to "very suitable", entire areas were classified as "very suitable" for planting.

\section{Results}

Natural conditions of golden camellias

All 6 studied golden camellias were distributed in the elevation range of $120-850 \mathrm{~m}$ above sea level (Table 1). Annual temperature was in a range of $20.8-22.8^{\circ} \mathrm{C}$, with the lowest temperature of $>$ $10.1-13.1{ }^{\circ} \mathrm{C}$ and the highest temperature of $<25.7-29.8^{\circ} \mathrm{C}$. The range of annual precipitation was larger, from 1,500 to $2,600 \mathrm{~mm}$. In general, golden camellias grow naturally in evergreen broadleaved forests. They can be found in both primary forest and/or secondary forest. Forest cover of $>30 \%$ is required for growth and development of golden camellias. Golden camellias prefer to grow in high moisture soil close to streams and in soil with deep layers. However, golden camellias are also found in dry and shallow soil. 
http://wjst.wu.ac.th

Table 1 Natural conditions of 6 golden camellias.

\begin{tabular}{|c|c|c|c|c|}
\hline $\begin{array}{l}\text { Scientific name } \\
\text { (Vietnamese } \\
\text { name) }\end{array}$ & $\begin{array}{c}\text { Distribution } \\
\text { elevation (m) }\end{array}$ & $\begin{array}{c}\text { Annual } \\
\text { temperature } \\
\left({ }^{\circ} \mathrm{C}\right) \\
\end{array}$ & $\begin{array}{c}\text { Annual } \\
\text { precipitation } \\
(\mathbf{m m}) \\
\end{array}$ & Vegetation characteristic \\
\hline $\begin{array}{l}\text { Camellia } \\
\text { impressinervis } \\
\text { (Chè hoa vàng } \\
\text { gân lõm) }\end{array}$ & $250-400$ & $\begin{array}{l}\text { Average: } \\
21.2 \\
\text { Min: } 13.1 \\
\text { Max: } 29.8\end{array}$ & $1,500-1,700$ & $\begin{array}{l}\text { Secondary tropical evergreen } \\
\text { broadleaved forests recovered } \\
\text { after selective logging with } \\
\text { forest cover of } 50-80 \% \text {. }\end{array}$ \\
\hline $\begin{array}{l}\text { Camellia } \\
\text { kirinoi }(\text { Chè hoa } \\
\text { vàng Kiri) }\end{array}$ & $350-360$ & $\begin{array}{l}\text { Average: } \\
21.2 \\
\text { Min: } 13.1 \\
\text { Max: } 29.8\end{array}$ & $1,500-1,700$ & $\begin{array}{l}\text { Secondary tropical evergreen } \\
\text { broadleaved forests recovered } \\
\text { after shifting cultivation and } \\
\text { selective logging with forest } \\
\text { cover of }>40 \% \text {. }\end{array}$ \\
\hline $\begin{array}{l}\text { Camellia tienii } \\
\text { (Hải đường } \\
\text { vàng/Chè hoa } \\
\text { vàng tiến) }\end{array}$ & $250-420$ & $\begin{array}{l}\text { Average: } \\
22.0 \\
\text { Min: } 13.0 \\
\text { Max: } 25.7\end{array}$ & $1,600-2,600$ & $\begin{array}{l}\text { Secondary and/or primary } \\
\text { tropical evergreen broadleaved } \\
\text { forests with forest cover of } 40- \\
70 \% \text {. }\end{array}$ \\
\hline $\begin{array}{l}\text { Camellia } \\
\text { tuyenquangensis } \\
\text { (Chè hoa vàng } \\
\text { Tuyên Quang) }\end{array}$ & $500-850$ & $\begin{array}{l}\text { Average: } \\
22.8 \\
\text { Min: } 12.9 \\
\text { Max: } 28.6\end{array}$ & $1,550-1,900$ & $\begin{array}{l}\text { Secondary and/or primary } \\
\text { tropical evergreen broadleaved } \\
\text { forests with forest cover > } \\
50 \% \text {. }\end{array}$ \\
\hline $\begin{array}{l}\text { Camellia } \\
\text { hamyenensis } \\
\text { (Chè hoa vàng } \\
\text { Hàm Yên) }\end{array}$ & $130-250$ & $\begin{array}{l}\text { Average: } \\
22.8 \\
\text { Min: } 12.9 \\
\text { Max: } 28.6\end{array}$ & $1,550-1,900$ & $\begin{array}{l}\text { Secondary tropical evergreen } \\
\text { broadleaved forests recovered } \\
\text { after shifting cultivation with } \\
\text { forest cover }>30 \% \text {. }\end{array}$ \\
\hline $\begin{array}{l}\text { Camellia } \\
\text { megasepala (Chè } \\
\text { hoa vàng Ba } \\
\text { Bể/Chè hoa vàng } \\
\text { đài lớn) }\end{array}$ & $120-160$ & $\begin{array}{l}\text { Average: } \\
20.8 \\
\text { Min: } 10.1 \\
\text { Max: } 29.7\end{array}$ & $1,600-1,800$ & $\begin{array}{l}\text { Primary tropical evergreen } \\
\text { broadleaved forests with forest } \\
\text { cover of } 60-80 \% \text {. }\end{array}$ \\
\hline
\end{tabular}

C. impressinervis was first planted in Cao Bang in 2013 as adult trees, which were dug up from natural forests and transplanted. Trees started blooming after 5 years. However, the number of flowers were limited, and marketing flowers and leaves of golden camellias in Cao Bang was not recorded. Meanwhile, planting of C. kirinoi, C. megasepala, C. tuyenquangensis, C. hamyenensis, and C. tienii has not been found in Cao Bang.

\section{Mapping}

Based on information in Table 1, each main condition was classified into 3 levels (Table 2), of which "very suitable" and "suitable" had to meet the requirements of all 3 main conditions (Table 2). If only 1 of 3 main conditions was met, it belonged to "not suitable" (Table 2). 
http://wjst.wu.ac.th

Table 2 Parameters with 3 levels for mapping.

\begin{tabular}{lccc}
\hline \multicolumn{1}{c}{ Main condition } & \multicolumn{3}{c}{ Level } \\
\cline { 2 - 4 } & Very suitable & Suitable & Not suitable \\
\hline Elevation above sea level $(\mathrm{m})$ & $150-400$ & $100-700$ & $<100$ and $>700$ \\
Annual precipitation $(\mathrm{mm})$ & $1,600-2,000$ & $1,400-2,400$ & $<1,400$ and $>2,400$ \\
Annual temperature $\left({ }^{\circ} \mathrm{C}\right)$ & $20-21$ & $19-23$ & $<19$ and $>23$ \\
\hline
\end{tabular}

There are 12 districts and 1 city belonging to Cao Bang province (Figure 2), of which 3 districts (Bao Lam, Nguyen Binh, and Thach An) had land areas which were "very suitable' for planting golden camellias (Table 3). The total of very suitable areas was $1,969.6$ ha, accounting for $0.3 \%$ of the land area of Cao Bang (Figure 2). Thirty-seven percent of the area of Cao Bang was classified as "not suitable" and $62.7 \%$ was classified as suitable for planting golden camellias (Table 3).

Table 3 Potential planting areas (ha) by districts in Cao Bang province.

\begin{tabular}{|c|c|c|c|c|}
\hline No & District, city & Very suitable & Suitable & Not suitable \\
\hline 1 & Bao Lac & \multirow{3}{*}{$1,331.9$} & $30,015.2$ & $61,990.5$ \\
\hline 2 & Bao Lam & & $47,068.4$ & $42,930.9$ \\
\hline 3 & Ha Lang & & $40,791.4$ & $4,999.5$ \\
\hline 4 & Ha Quang & \multirow{4}{*}{185.1} & $13,748.2$ & $31,553.3$ \\
\hline 5 & Hoa An & & $55,762.0$ & $4,982.1$ \\
\hline 6 & Nguyen Binh & & $38,007.6$ & $45,618.7$ \\
\hline 7 & Phuc Hoa & & $12,833.7$ & $12,370.5$ \\
\hline 8 & Quang Uyen & \multirow{6}{*}{452.5} & $34,958.1$ & $3,480.4$ \\
\hline 9 & Thach An & & $65,357.9$ & $3,270,8$ \\
\hline 10 & Thong Nong & & $22,137.4$ & $13,582.4$ \\
\hline 11 & Cao Bang city & & $10,752.7$ & \\
\hline 12 & Tra Linh & & $9,202.5$ & $16,045.8$ \\
\hline 13 & Trung Khanh & & 39451.8 & $7,227.3$ \\
\hline \multicolumn{2}{|c|}{ Total (ha) } & $1,969.6$ & $420,086.7$ & $248,052.1$ \\
\hline \multicolumn{2}{|c|}{$\begin{array}{l}\text { Percentage of total provincial } \\
\text { land area }(\%)\end{array}$} & 0.3 & 62.7 & 37.0 \\
\hline
\end{tabular}

Mapping results indicated that planted areas of around 500 C. impressinervis trees were "suitable" areas in Thach An district (Figure 2). All areas with natural distributions of $C$. impressinervis and $C$. kirinoi, 2 species with natural distributions in Cao Bang, were "very suitable" and "suitable" areas. This indicated the accuracy of the mapping in this work. 
http://wjst.wu.ac.th

\section{Discussion}

No plants can grow out of their elevation requirements. This prerequisite holds true for golden camellias, as no trees were found to have natural distribution above $850 \mathrm{~m}$ elevation. Air temperature is also an important requirement. Too low a temperature $\left(<10^{\circ} \mathrm{C}\right)$ in winter/blooming season will have an effect on flowers, which causes the death of young flower buds. Elevation and air temperature are 2 natural conditions that planters generally cannot control. Therefore, these are 2 prerequisite conditions for the mapping of planting areas for any tree species. Meanwhile, watering (representing precipitation) can also be applied if one plants golden camellias in low precipitation areas. However, this is costly and difficult to apply in low economic condition of ethnic communities in Cao Bang. Therefore, precipitation should also be considered as a prerequisite condition.

Golden camellias are classified as shrubs and/or small-sized trees which are under $12 \mathrm{~m}$ tall at maturity [2,7,14,21]. These are shade-tolerant plants which can only grow under shading. This characteristic is different from that of shade-intolerant species, which require shading only for seedlings and saplings [22]. Therefore, forest canopy is important for growing golden camellias. It is recommended that golden camellias must be planted under the canopy of natural forests and plantations, ranging from $40-70 \%$ depending on specific golden camellias. However, one may grow golden camellias on bared land. In that case, artificial shading and/or growing other tree species for shading are required and feasible for the success of planting golden camellias. In addition, growing under shade of forest with cover $>70 \%$ could be feasible if one can reduce forest cover to the suitable level required by each specific species and growth stage. Edaphic condition is also an important factor for growing golden camellias, which prefer to grow in deep layers and fertile soil. However, one may grow golden camellias in shallow and less fertile soil. In that case, fertilization should be applied for better growth and development of planted trees. It is recommended that, firstly, golden camellias should be planted only in "very suitable" areas. If they are not allowed to grow in "very suitable" areas because of protected forests, local people can plant them in "suitable" areas, with consultation from local authorities and experts to ensure the best growth and flowering of planted trees.

As mentioned, most populations in Cao Bang are ethnic minorities who live in very low conditions compared to other parts of Vietnam. Applying new techniques and/or extensive cultivation for golden camellias seems to be infeasible because of low economic conditions. Therefore, it is recommended that local people only plant golden camellias in "very suitable" areas. Otherwise, growing in bared land requires huge investment for both artificial shading and/or growing other tree species for shading. In addition, technique guidelines for planting and maintaining golden camellias must be communicated in detail to ethnic people.

This work is the first step showing where golden camellias can be planted. However, for growing any species successfully and beneficially, many aspects are required; for example, (1) selecting best cultivars, (2) techniques for producing best seedlings, and (3) growing, planting, and maintaining techniques. Such topics should be further studied, then recommended for practical applications. For experimentation, golden camellias must be planted in "very suitable" areas (Figure 2). In terms of species, C. impressinervis is firstly recommended for planting in Cao Bang, because this species is naturally distributed in Cao Bang and has large-sized and heavily yellow flowers [17] compared to $C$. kirinoi (Figure 1) [16], which also has natural distribution in Cao Bang with much smaller flowers. Growing the other 4 species (Table 1) should be conducted in trials for evaluation before recommendation for practical application, since these 4 species have not been found to be naturally distributed in Cao Bang.

Currently, $1 \mathrm{~kg}$ dry flowers of golden camellias cost 600 - 700 US\$. Such a high price results from the high health care value and low productivity of golden camellias in Vietnam, which has been estimated to be less than several tons of dry flowers per year [14]. If supply increases, then the price will decrease as a relation of market and consumption. Therefore, how many areas golden camellias should be planted in is a challenging question which policymakers, market developers, scientists, and local ethnic people 
http://wjst.wu.ac.th

must closely work together for in order to produce an optimal, feasible, and sustainable plan. Otherwise, the planting of golden camellias will become similar to other crops in Vietnam, such as coffee, cacao, and pepper; overplanting will lead to high productivity and low price, resulting in low benefit.

\section{Conclusions}

Golden camellias are potential plants for poverty reduction in local communities, as their active ingredients are well known for human health, leading to a high market price of dry flowers. This work showed potential planting areas in Cao Bang province, North Vietnam. Total areas, which are very suitable for growing golden camellias, cover 1,969.6 ha, accounting for $0.3 \%$ of the total natural land area of Cao Bang, while $62.7 \%$ of land is suitable, and $37.0 \%$ is not suitable.

To grow golden camellias successfully, further studies on selecting cultivars, producing seedlings, and improving planting and maintaining techniques must be carried out, then recommended for application. In addition, studies on processing flowers and leaves should be conducted to have more economically valuable products than dry flowers and leaves, as currently sold in the markets. $C$. impressinervis is first recommended for planting, as it has natural distribution in Cao Bang and its flowers are bigger than others.

\section{Acknowledgements}

This research is funded by the Vietnam Ministry of Science and Technology under grant number 17/18/ĐTĐL.CN-ĐP. We would like to thank anonymous reviewers for constructive comments on the manuscript.

\section{References}

[1] WM Hansen. The 3rd international academic forum on yellow camellias: A personal view. Int. Camellia J. 2013; 7, 17-9.

[2] T Ninh. Biodiversity of camellia genus of Viet Nam. In: Proceedings of the $1^{\text {st }}$ National Symposium on Yellow Camellia of Viet Nam, Tam Dao, Viet, 2003.

[3] SY Liang. The discovery and name of Camellia nitidissima. Chin. Plants 1992; 5, 7.

[4] NNH Le, C Uematsu, H Katayama, LT Nguyen, N Tran, DV Luong and TS Hoang. Camellia tuyenquangensis (Theaceae), a new species from Vietnam. Korean J. Plants Toxon. 2017; 47, 95-9.

[5] LV Dung, L Anna, NT Hanh and NT Lieu. Camellia thuongiana: A new yellow camellia species from Vietnam. Dalat Univ. J. Sci. 2016; 6, 338-44.

[6] T Ninh and LNH Ninh. Diversity of wild camellia species of Tam Dao National Park. J. Sci. Nat. Sci. Tech. 2007; 23, 52-154.

[7] T Ninh. Results of study on yellow camellias of Viet Nam. Int. Camellia J. 2003.

[8] CG Pereira, L Barreira, S Bijttebier, L Pieters, V Neves, MJ Rodrigues, R Rivas, J Varela and L Custodio. Chemical profiling of infusions and decoctions of Helichrysum italicumsub sp. picardii by UHPLC-PDA-MS and in vitro biological activities comparatively with green tea (Camellia sinensis) and rooibos tisane (Aspalathus linearis). J. Pharmaceut. Biomed. Anal. 2017; 145, 295603.

[9] J Qi, R Shi, J Yu, Y Li, S Yuan, J Yang, J Hu and A Jia. Chemical constituents from leaves of Camellia nitidissima and their potential cytotoxicity on SGC7901 Cells. Chin. Herb. Med. 2016; 8, 80-4.

[10] JB Wei, X Li, H Song, YH Liang, YZ Pan, JX Ruan, X Qin, YX Chen, CL Nong and ZH Su. Characterization and determination of antioxidant components in the leaves of Camellia chrysantha (Hu) Tuyama based on composition activity relationship approach. J. Food Drug Anal. 2015; 23, 40-48. 
http://wjst.wu.ac.th

[11] Guangxi Institute of Botany. Guangxi Flora. Guangxi Science and Technology Press, Nanning. 1991.

[12] YL Huang, YY Chen, YX Wen, DP Li, RG Liang and X Wei. Effects of the extracts from Camellia nitidssimas leaves on blood lipids. Lishizhen Med. Mater. Med. Res. 2009; 4, 5.

[13] XM Qin, HJ Lin, EC Ning and W Lu. Antioxidative properties of extracts from the leaves of Camellia chrysantha (Hu) Tuyama. Food Sci. Tech. 2008; 2, 189-91.

[14] VD Tran. Overview of Golden camellias in Cao Bang. Silviculture Research Institute, Hanoi, Vietnam, 2018.

[15] L Wheeler and MC Rivers. Camellia Impressinervis. The IUCN Red List of Threatened Species. 2015.

[16] T Ninh. Camellia kirinoi: A new species and precious gene resource should be conserved. J. Genet. Appl. 1999; 2, 37-8.

[17] TC Hung and LS Ye. Camellia impressinervis. Acta Sci. Nat. Univ. Sunyatseni. 1979; 18, 72.

[18] JH Vargas, T Consiglio, PM Jorgensen and TB Croat. Modelling distribution patterns in a speciesrich plant genus, Anthurium (Araceae), in Ecuador. Divers. Distrib. 2004; 10, 211-6.

[19] H Choe, JH Thorne and C Seo. Mapping national plant biodiversity patterns in South Korea with the MARS species distribution model. Plos One 2016; 11, 0149511.

[20] C Wu, Q Xiao and EG McPherson. A method for locating potential tree-planting sites in urban areas: A case study of Los Angeles, USA. Urban For. Urban Gree. 2008; 7, 65-76.

[21] T Ninh and N Hakoda. Three new species of the genus Camellia from Viet Nam. Int. Camellia J. 1998; 30, 76-9.

[22] HV Thang, DT Trieu, HV Thanh, PD Trung, CV Lang, NT Dien and VD Tran. Promoting reforestation through supplementing native forest tree species in Northwestern, Vietnam. Asian J. Agric. Biol. 2018; 6, 300-7. 